Research.

\title{
Marketing priority analysis based on marketing mix in Luvrina Fashion
}

\author{
Ragil Pardiyono \\ Universitas Jenderal Achmad Yani Bandung \\ ragilpardiyono@gmail.com \\ Rina Indrayani \\ Sekolah Tinggi Teknologi Bandung \\ rina@sttbandung.com
}

\begin{abstract}
Received: July 25, 2019; Accepted: August 12, 2019; Published: December 31, 2019
To cite this article: Pardiyono, Ragil, Rina Indrayani. 2019. Marketing Priority Analysis Based on Marketing Mix in Luvrina Fashion. The Management Journal of BINANIAGA. 4 (2): 45-54. doi: 10.33062/mjb.v4i2.335
\end{abstract}

\begin{abstract}
Abstracst. Luvrina Fashion is a specialty clothing store located in the mature woman Jatinangor Town Square. Fashion Luvrina sales value in recent months has decreased. As the Micro, Small, Medium, he needs a business management that consists of financial management, marketing, production, distribution, and human resources to conduct its business. Marketing aspect is an important factor for companies to carry out his life (Bayu Promukoto, 2018). Thus the purpose of this research is the analysis of marketing priorities based model of the marketing mix. Tools of data collection using a questionnaire with 23 variables and the respondents as many as 100 visitors. The method used is the analysis of factors with steps Preparing Raw Data Matrix, Matrix Correlation between Variables, Calculations Eigenvalue, Extraction of factors, weighting factors, Rotation Factor, and determination of manifest variables that Form Factor. The results of data processing that marketing priorities with marketing mix models in a fashion luvrina is factor 1 has eigenvalue equal to 17.950 which includes the availability of diverse models of clothes, clothing quality, low price, method of payment by debit card, as well as their discount. The next priority is a factor 2 , factor 3 , a factor of 4 , and a factor of 5 .
\end{abstract}

Keywords: Marketing, Marketing Mix, Factor Analysis

\section{Background}

Luvrina Fashion is a women's clothing store Jatinangor adults located in the Town Square. Jatinangor Town Square or JATOS is one of the shopping center / mall in the border area of Bandung Sumedang. JATOS located in a very strategic location, on Highway Jatinangor No. 150 Sumedang, which is the main route of West Java Province and is located between four major universities in West Java, namely IPDN, ubuntu, ITB and IKOPIN as well as large scale industries. It makes JATOS as a potential place for entrepreneurship and strategic place to be used as a spot of shopping, dining and recreational for the surrounding community.

Fashion Luvrina sales value in recent months has decreased. This can be seen in the chart below, 


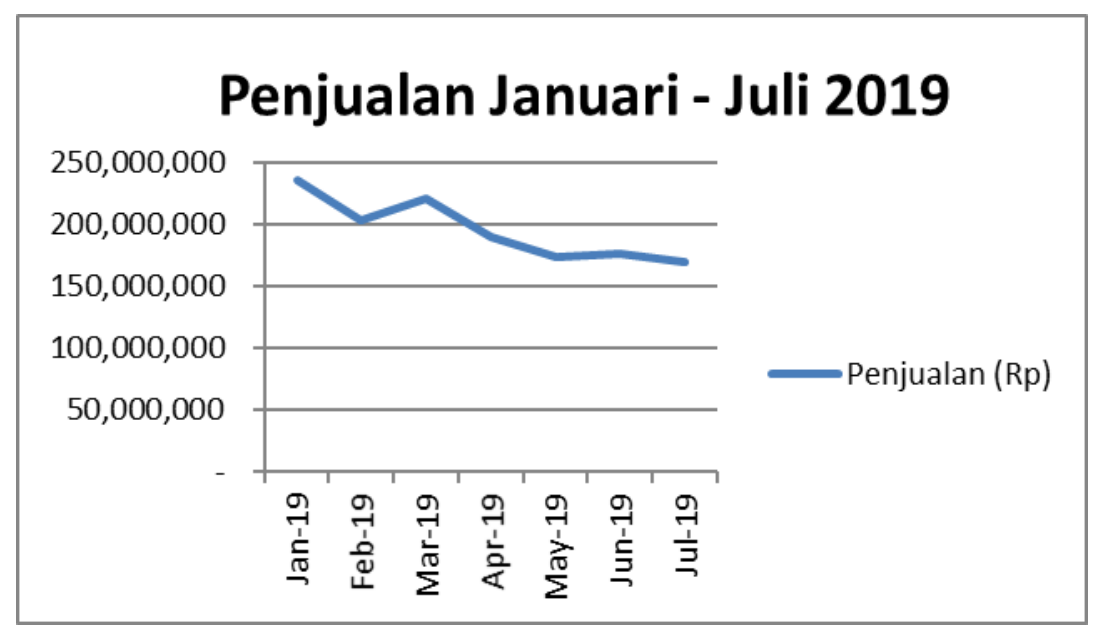

Figure: Graph of sales Jan-July 2019

Luvrina Fashion is Micro Small Medium Enterprises that require business management in carrying out His attempt. Business management consists of financial management, marketing, Production, distribution, and human resources. Marketing aspect is an important factor for companies to establish their lives. Thus the purpose of this research is the analysis of marketing priorities based model of the marketing mix.

\section{Library Review}

According to Kotler and Keller in Pardiyono and Indrayani Marketing Mix is a set of integrated marketing tool by companies to produce the desired response target market. The dimensions of the marketing mix is a place, product, promotion, price, people, physical evidence and process.

In this study the mean dimension of the marketing mix is as follows:

a) Place is where the store is located.

b) Product is all kinds of clothes there in the store.

c) Promotion, is all the work done by the shop to introduce their products to the market.

d) Price, is the amount of money paid by the clothing purchased kosumen

e) People, are the people who are directly involved in running the business.

f) Physical Evidence is the real thing.

g) Process an attempt to execute and carry out activities to meet the needs and desires of consumers quickly and accurately.

According Simamora the sample size is based on analytical techniques such as factor analysis, the recommended sample size is not less than 50 observations, and suggested a sample size of 100 or more. Do not do the factor analysis if the sample size is less than 50 . However, this provision is not absolute. As a general rule, the number of respondents is minimal (sometimes also referred to a case or observation, the authors) is three times the number of variables.

\section{Method of Research}

\section{Validity Test and Reliability Test}

According to Sitinjak and Sugiarto validity associated with a variable measure what should be measured. The validity of the study states the degree of accuracy of the measuring instrument to the study measured the actual content. Validity test is a test that is used to indicate the extent of measuring instruments used in a measure what is being measured. Ghozali states that the validity of the test used to measure invalid or valid 
whether or not a questionnaire. A questionnaire considered valid if the questions in the questionnaire were able to reveal something that will be measured by the questionnaire.

If the count $r \geq r$ table (test 2 sides with sig. 0.05), the instruments or items significantly correlated questions to the total score (declared invalid). Determine the validity of the instrument that the reference category in the classification as follows:

1. $0.80<1.00$ validity excellent (very high)

2. $0.60<0.80$ validity excellent (high)

3. $0.40<0.60$ validity sufficient (medium)

4. $0.20<0.40$ validity of less (low)

5. $0.00<0.20$ validity ugly (very low)

6. 0.00 Invalid

Sitinjak and Sugiarto states that reliability refers to an understanding that the instruments used in the study to obtain reliable information used as a means of data collection and to reveal the actual information field. Ghozali states that reliability is a tool to measure a questionnaire which is an indicator of variables or constructs. A questionnaire said to be reliable or reliable if someone answers on the statement is consistent or stable over time. The reliability of a test refers to the degree of stability, consistency, predictability, and accuracy. Measurements have high reliability is a measure that can produce reliable data.

High and low reliability, empirically demonstrated by a number called the coefficient of reliability. High reliability shown by the value approaching 1 . The agreement is generally considered sufficient reliability satisfactory if $\geq 0.700$. Reliability coefficient category is as follows:

1. $0.80<1.00$ reliability is very high.

2. $0.60<0.80$ high reliability.

3. $0.40<0.60$ reliability was.

4. $0.20<0.40$ lower reliability

\section{Factor analysis}

According to Santoso Factor analysis is a branch of statistics and also an analytical technique that involves inter-dependencies between variables, which basically tries to simplify the problem for easy interpretation through the depiction of patterns of relationships or data reduction. This is done by identifying the structure contained in the set of observed variables.

One of the goals to be achieved in the factor analysis is to simplify the relationships are complex and diverse, in a set of variables studied by finding the dimensions or the common factor linking the variables that appear to be unrelated. Thus providing an understanding of the basic structure.

There are three general functions of the analysis of factors, including the following:

1. Reducing the number of study variables to keep using the information that has been obtained as much as possible. Number of baseline variables could be reduced to number fewer variables to consider as variance data.

2. Provide qualitative and quantitative differences in a relatively large amount of data.

3. Hypotension test on qualitative and quantitative differences in the data.

Factor analysis seeks to simplify the complex and diverse relationships in a set of variables studied to find the dimensions or general factors (common factor) variables that connects seemingly unrelated, thus providing an understanding of the basic structure.

Analysis of factors can reduce the manifest variable data into a number of latent variables are less by utilizing the degree of relationship between variables. The relationship between the manifest variables with latent variables is given by weighting factor (factor loading). To get a breakdown of the manifest variables in a latent variables, each variable manifest should be calculated more manifest variable correlation with the latent variables are established.

Ragil Pardiyono and Rina Indrayani. Marketing Priority Analysis Based on Marketing Mix in Luvrina Fashion 
Latent variables with each other latent variables have the orthogonal relationship. Which means that there is no correlation between these variables. Formed latent variables can not be considered throughout the variance contained in each variable manifest. The remainder of the variance of each variable is described by error or mistake.

The basic model of the factor analysis are:

$$
\mathrm{X}=\mathrm{AF}+\varepsilon
$$

$$
\begin{aligned}
\text { Where: } \mathrm{X} & =\text { Vector dimensional response } \mathrm{p} \\
\mathrm{F} & =\text { general factor dimensionless vector } \mathrm{q} \\
\varepsilon & =\text { Vector of unique factors (Unique factor) dimension } \mathrm{p} \\
\text { Pxq A } & =\text { matrix containing weighting factors. }
\end{aligned}
$$

Calculation of factor analysis consisted of the following stages:

1. Determining the raw data matrix $X(m \times n), m$ is the number of observation units and $n$ is the number of variables specified.

2. Standardize the raw data matrix $X(m \times n)$.

3. Determine the correlation matrix $R(x n)$ between variables.

4. Extraction of factors early. At this stage, data reduction, resulting in a number of factors that are independent from one lain.hasil at this stage is a matrix of factors that have not been rotated.

5. Rotation factor for the final factor. Which has not been rotated factor matrix can contain the same variable on several factors, so it will complicate data interpretation. Therefore do rotation factor which aims to get the simplicity and ease of data interpretation.

6. This factor analysis method chosen for its ability to reduce the number of variables to simplify subsequent analysis.

Several factors analysis techniques include:

1. Principal component analysis (principal components analysis);

2. Common factor analysis (common factor analysis),
a) Principal factor analysis;
b) Alpha analysis;
c) Image Factor analysis;
d) Canonical Factor analysis;
e) Maxsimum Likelihood Analysis;
f) Principal - Axsis Factoring;
g) Unweighted Least - Squares;
h) Generalized Least - Squares;

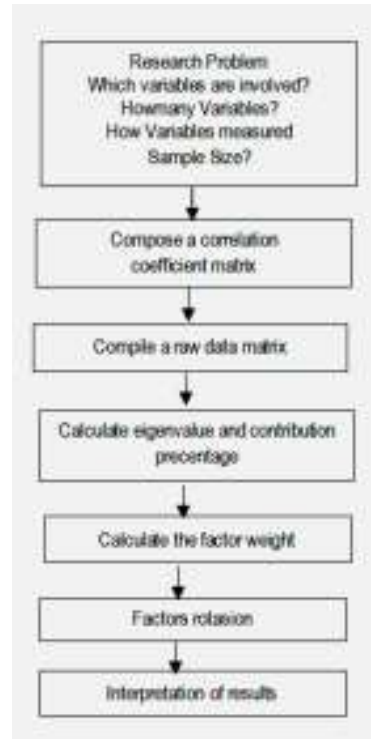

Ragil Pardiyono and Rina Indrayani. Marketing Priority Analysis Based on Marketing Mix in Luvrina Fashion 


\section{Results and Discussion}

\section{Test Validity and Test Reliability}

The coefficient is generated for each variable item will then be compared with the critical number that corresponds to the degree of freedom in the test. By interpolating, obtained in significant correlation table with $5 \%$ is critical number $r$ its value is 0.3610 . All variables have the $\mathrm{F}$-table $>\mathrm{F}$ Calculate which means that all variables were valid.

The reliability test using Cronbach Alpha method. Data is said to be reliable if the Cronbach's alpha values greater than 0.60 . Results of testing the reliability of the questionnaire can be seen in the table below.

Table. Results of Test Reliability

\begin{tabular}{|r|r|}
\hline \multicolumn{2}{|c|}{ Reliability Statistics } \\
\hline $\begin{array}{c}\text { Cronbach's } \\
\text { Alpha }\end{array}$ & N of Items \\
\hline, 959 & 23 \\
\hline
\end{tabular}

Reliability coefficient value above is 0959 . This value is greater than 0.60 , then the items on the statement of the questionnaire has good reliability value and reliable for data collection, in other words the data of the questionnaire can be dipercay

\section{Factor Analysis}

\section{Develop Raw Data Matrix}

Data obtained from the answers of respondents are arranged in a matrix and the matrix is called a raw data matrix. This raw data matrix in the order $m \times n$, where:

$\mathrm{m}=$ line, a number of individuals (respondents) of 100 .

$\mathrm{p} \quad=$ is the number of variables (questions) at 23.

\section{Matrix Correlation Coefficient between Variables}

From the results of the raw data can be made a correlation matrix between the variables manifest that express the degree of relationship (correlation) between each variable. The correlation between these variables will be the essential ingredients to form factors of similarity of each variable.

Before entering the stage of eigenvalues calculation, statistical analysis of factors should be tested for feasibility. Factor analysis can be concluded whether or not the test of Kaiser-Mayer-Olkin (KMO) measure of adequacy and Berlett Test of spericity. KMO test value ranges between 0 and 1 have questioned the feasibility of (appropriateness) of factor analysis. If the index value is high (between 0.5 to 0.1 ), factor analysis feasible.

Table. Test Results KMO and Berlett Test

\begin{tabular}{|l|l|r|}
\hline \multicolumn{3}{|c|}{ KMO and Bartlett's Test } \\
\hline Kaiser-Meyer-Olkin Measure of Sampling Adequacy. &, 882 \\
\hline \multirow{2}{*}{$\begin{array}{l}\text { Bartlett's Test of } \\
\text { Sphericity }\end{array}$} & Approx. Chi-Square & 6318.843 \\
\cline { 2 - 3 } & df & 1275 \\
\cline { 2 - 3 } & Sig. &, 000 \\
\hline
\end{tabular}

From the table above the $\mathrm{KMO}$ and Barlett Test shows that the overall $\mathrm{KMO}$ value is 0882. Barlett test is a statistical test to test whether it really involved variables correlated. Value Bartlett test was approached by chi-square value. Table 1 shows that the chi-square value is 6318.843 degrees of freedom in 1275 , and has significance 0.000 . In conclusion, that the correlation between variables have. 
From the anti-image correlation table, it appears that the value of MSA (Measures of Sampling Adequacy) above 0.5 , so the factor analysis is feasible to do so can be analyzed further. In addition to test Kaiser-Mayer-Olkin (KMO) measure of adequacy and Berlett Test of spericity, note also how much variance can be explained by factors that are extracted.

Table. Communalities

communalities

\begin{tabular}{|c|r|r|}
\hline & \multicolumn{1}{|c|}{ Initial } & extraction \\
\hline Product1 & 1 & 0,656 \\
\hline product2 & 1 & .748 \\
\hline Product3 & 1 & 0.754 \\
\hline Product4 & 1 & 0.562 \\
\hline Price1 & 1 & 0.627 \\
\hline Pric2 & 1 & .681 \\
\hline Place1 & 1 & .834 \\
\hline Place2 & 1 & 0,795 \\
\hline place3 & 1 & 0.668 \\
\hline Place4 & 1 & 0.665 \\
\hline $\begin{array}{c}\text { Promotion } \\
1\end{array}$ & 1 & 0.717 \\
\hline $\begin{array}{c}\text { Promotion } \\
2\end{array}$ & 1 & 0,806 \\
\hline
\end{tabular}

\section{communalities}

\begin{tabular}{|c|r|r|}
\hline & \multicolumn{1}{|c|}{ Initial } & extraction \\
\hline $\begin{array}{c}\text { Promotion } \\
3\end{array}$ & 1 & .814 \\
\hline $\begin{array}{c}\text { Promotion } \\
4\end{array}$ & 1 & 0,781 \\
\hline $\begin{array}{c}\text { Promotion } \\
5\end{array}$ & 1 & .923 \\
\hline People1 & 1 & 0.697 \\
\hline People2 & 1 & 0.742 \\
\hline People3 & 1 & 0,746 \\
\hline process1 & 1 & .709 \\
\hline process2 & 1 & 0.825 \\
\hline Process3 & 1 & .713 \\
\hline Physical1 & 1 & .670 \\
\hline Physical2 & 1 & 0.739 \\
\hline
\end{tabular}

Extraction Method: Principal

Component Analysis.

The above table shows Product 1 worth 0656, meaning Product1can explain a factor of $65.6 \%$. Similarly, the other variables, where all worth $>50 \%$ can be concluded that all variables can explain factors. The greater the value of the variable means communalities an increasingly close relationship with the variables that are formed.

\section{Eigen value calculation}

In the analysis of the total variance illustrates eigenvalue factor described by each factor. From the analysis it was formed five factors. Factor 1 has eigenvalue equal to 17.950, which means that this factor explains $17.95 \%$ or 35196 . It turned out to be five (5) factors that had eigenvalues of magnitude greater than or equal to 1 . The value of the order of magnitude of eigenvalue reflects the ability of a factor in explaining of the total.

This study used the criteria of eigenvalues $>=1$ to determine whether a factor worth taking or not. It turned out that by using this criterion we obtain five (5) factors are mutually orthogonal. With these five factors the result of cumulative percentage variance $82.597 \%$ or in other words there is a $17.403 \%$ variance which is not represented by these five factors.

Ragil Pardiyono and Rina Indrayani. Marketing Priority Analysis Based on Marketing Mix in Luvrina Fashion 
Table. Total Variance Explained

Total Variance Explained

\begin{tabular}{|c|c|c|c|c|c|c|c|c|c|}
\hline \multirow{2}{*}{ Component } & \multicolumn{3}{|c|}{ Initial Eigenvalues } & \multicolumn{3}{c|}{ Extraction Sums of Squared } & \multicolumn{3}{c|}{ Rotation Sums of Squared } \\
& Total & $\begin{array}{c}\text { \% Of } \\
\text { Variance }\end{array}$ & $\begin{array}{c}\text { Cumula } \\
\text { tive } \%\end{array}$ & Total & $\begin{array}{c}\text { \% Of } \\
\text { Variance }\end{array}$ & $\begin{array}{c}\text { Cumula } \\
\text { tive\% }\end{array}$ & Total & $\begin{array}{c}\% \text { Of } \\
\text { Variance }\end{array}$ & $\begin{array}{c}\text { Cumula } \\
\text { tive\% }\end{array}$ \\
\hline 1 & 17.950 & 35.196 & 35.196 & 17.950 & 35.196 & 35.196 & 9.319 & 18.273 & 18.273 \\
\hline 2 & 11.415 & 22.657 & 57.853 & 11.415 & 22.657 & 57.853 & 6.447 & 28.720 & 46.993 \\
\hline 3 & 9.402 & 12.711 & 70.564 & 9.402 & 18.711 & 75.563 & 6,799 & 14.329 & 61.322 \\
\hline 4 & 2,209 & 4.331 & 74.895 & 2,209 & 4.331 & 79.895 & 4,813 & 9.177 & 70.499 \\
\hline 5 & 1,888 & 3.547 & 78.442 & 1,888 & 3.702 & 82.597 & 2,599 & 12.080 & 82.579 \\
\hline 6 &, 934 & 3,194 & 81.636 & & & & & & \\
\hline 7 &, 922 & 2.924 & 84.560 & & & & & & \\
\hline 8 &, 799 & 2.867 & 87.427 & & & & & & \\
\hline 9 &, 738 & 2.416 & 89.843 & & & & & \\
\hline 10 &, 691 & 2,359 & 92.202 & & & & & & \\
\hline 11 &, 646 & 2,057 & 94.259 & & & & & & \\
\hline 12 &, 572 & 1.963 & 96.222 & & & & & \\
\hline 13 &, 562 & 0.831 & 97.053 & & & & & \\
\hline 14 &, 504 & .809 & 97.862 & & & & & & \\
\hline 15 &, 475 & 0.567 & 98.429 & & & & & & \\
\hline 16 &, 455 & 0,447 & 98.876 & & & & & \\
\hline 17 &, 434 & .356 & 99.232 & & & & & & \\
\hline 18 &, 422 & 0,266 & 99.498 & & & & & & \\
\hline 19 & 399 & 0.122 & 99.620 & & & & & \\
\hline 20 &, 338 & 0.102 & 99.722 & & & & & & \\
\hline 21 &, 291 & .098 & 99.820 & & & & & \\
\hline 22 &, 246 & 0.091 & 99.911 & & & & & \\
\hline 23 &, 172 & 0.089 & 100,000 & & & & & \\
\hline
\end{tabular}

\section{Extraction factor}

Extraction factor in this study using the method of the main components. In this case the main determinant is the eigenvalue $>=1$. It turned out to be five (5) factors that had eigenvalues of magnitude greater than or equal to 1 .

\section{Weighting factor}

The next phase to determine the dominant items on each component, as well as to see how big the correlation between variables and factors formed.

\section{Rotation factor}

Rotation factor is done by using varimax method, which is an orthogonal rotation technique. Rotation is necessary because it contains dominant variables that overlap each other. By doing this rotation, the variables can be grouped with the dominant turns better on each of the factors making interpretation easier. How to create item correlation approaching absolute values 1 and 0 on each factor so as to facilitate the interpretation of the dominant item.

\section{Determination of the Form Factor Manifest Variables}

This stage is the last stage in the process of factor analysis. After the rotation, we can easily determine the variables that make up the manifest which each factor. Below will be presented table manifest variables forming factors.

Ragil Pardiyono and Rina Indrayani. Marketing Priority Analysis Based on Marketing Mix in Luvrina Fashion 
Table. Variables Factors Shaping Manifesto

\begin{tabular}{|c|c|c|c|}
\hline Factor & Code & Question & Loading \\
\hline \multirow{6}{*}{ factor 1} & Product3 & $\begin{array}{l}\text { In a fashion shop you consider important } \\
\text { number of models available? }\end{array}$ & 0754 \\
\hline & Product1 & $\begin{array}{l}\text { In a fashion shop you consider important quality } \\
\text { of the material? }\end{array}$ & 0666 \\
\hline & Price1 & $\begin{array}{l}\text { In the shop you consider important fashion } \\
\text { cheap price? }\end{array}$ & 0539 \\
\hline & Prom1 & $\begin{array}{l}\text { In a fashion shop you consider important } \\
\text { method of payment with a debit card? }\end{array}$ & 0505 \\
\hline & Product4 & $\begin{array}{l}\text { In a fashion shop you consider important stock } \\
\text { of products and prices vary? }\end{array}$ & 0502 \\
\hline & Price2 & $\begin{array}{l}\text { In a fashion shop you consider important } \\
\text { discounts or rebates? }\end{array}$ & 0499 \\
\hline \multirow{4}{*}{ factor 2} & Place1 & $\begin{array}{l}\text { In a fashion shop you consider it important that } \\
\text { the store clean? }\end{array}$ & 0776 \\
\hline & Place2 & $\begin{array}{l}\text { In the shop you consider important fashion } \\
\text { sweet shop? }\end{array}$ & 0660 \\
\hline & Proses 1 & $\begin{array}{l}\text { In a fashion shop you consider important } \\
\text { friendly service? }\end{array}$ & 0657 \\
\hline & Proses2 & $\begin{array}{l}\text { In a fashion shop you consider important fast } \\
\text { service? }\end{array}$ & 0599 \\
\hline \multirow{5}{*}{ factor 3} & Physical1 & $\begin{array}{l}\text { In a fashion shop you consider important the } \\
\text { availability of seats? }\end{array}$ & 0575 \\
\hline & Physical2 & $\begin{array}{l}\text { In a fashion shop you attach importance to } \\
\text { availability fitingroom? }\end{array}$ & 0561 \\
\hline & place3 & $\begin{array}{l}\text { In the shop you consider important fashion } \\
\text { design an attractive storefront? }\end{array}$ & 0629 \\
\hline & Place4 & $\begin{array}{l}\text { In a fashion shop you consider important good } \\
\text { lighting store? }\end{array}$ & 0648 \\
\hline & product2 & $\begin{array}{l}\text { In a fashion shop you consider it important that } \\
\text { the present models? }\end{array}$ & 0762 \\
\hline \multirow{3}{*}{ factor 4} & Prom4 & $\begin{array}{l}\text { In a fashion shop you consider important } \\
\text { reference shop of advertising in social media? }\end{array}$ & 0525 \\
\hline & Prom5 & $\begin{array}{l}\text { In a fashion shop you consider important their } \\
\text { consumer membership card? }\end{array}$ & 0473 \\
\hline & People2 & $\begin{array}{l}\text { In your fashion shop employee considers it } \\
\text { important that interesting? }\end{array}$ & 0458 \\
\hline \multirow{5}{*}{ factor 5} & Prom2 & $\begin{array}{l}\text { In a fashion shop you consider important } \\
\text { method of payment by credit card? }\end{array}$ & 0777 \\
\hline & Prom3 & $\begin{array}{l}\text { In a fashion shop you consider important do } \\
\text { payments with e-money? }\end{array}$ & 0666 \\
\hline & People 1 & $\begin{array}{l}\text { In a fashion shop you consider it important that } \\
\text { employees use a neat clothing? }\end{array}$ & 0592 \\
\hline & People3 & $\begin{array}{l}\text { In your fashion shop employee considers it } \\
\text { important that the fragrance? }\end{array}$ & 0551 \\
\hline & Proses3 & $\begin{array}{l}\text { In a fashion shop you consider important } \\
\text { services that describe your product? }\end{array}$ & 0492 \\
\hline
\end{tabular}

\section{Conclusion}

Based on data processing and analysis has been done in the previous section, it can be dikesimpulkan that marketing priorities with marketing mix models in a fashion luvrina is factor 1 has eigenvalue equal to 17.950 which includes the availability of a variety of models,

Ragil Pardiyono and Rina Indrayani. Marketing Priority Analysis Based on Marketing Mix in Luvrina Fashion 
quality clothing, cheap price, method of payment by debit card, as well as their discount. The next priority is a factor 2 , factor 3 , a factor of 4 , and a factor of 5 .

\section{References}

Pardiyono, R., \& Indrayani, R. (2019, April). Decision Support System to Choose Private Higher Education Marketing Mix Models Based on The Criteria in Indonesia. In IOP Conference Series: Materials Science and Engineering (Vol. 508, No. 1, p. 012 112). IOP Publishing.

Simamora, B. (2005). Multivariate Analysis of Marketing. Gramedia Pustaka Utama.

Sitinjak, TJ Sugiarto. 2006. LISREL. Yogyakarta: Graha Science.

Ghozali, I. (2009). SPSS. Multivariate Analysis with SPSS Program. Agency Undip Publisher: Semarang.

Santoso, S. (2003). SPSS Statistics Multivariate, PT. Elex Media Komputindo, Jakarta. 
The Management Journal of BINANIAGA Vol. 04, No. 02, December 2019

p-ISSN: 2527 - 4317, e-ISSN: $2580-149 x$

$6^{\text {th }}$ Accreditation Rating: April 04, 2019-April 03, 2024

This page intentionally be emptied.

Ragil Pardiyono and Rina Indrayani. Marketing Priority Analysis Based on Marketing Mix in Luvrina Fashion 